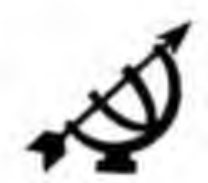

\title{
Toepassing van moraliteit in die Suid-Afrikaanse staatsdiens
}

\author{
David Fourie \\ Skool vir Openbare Bestuur en Administrasie \\ Fakulteit Ekonomiese en Bestuurswetenskappe \\ Universiteit van Pretoria \\ PRETORIA \\ E-pos: djfourie@hakuna.up.ac.za
}

\begin{abstract}
The application of morality in the South African public service

Change in the South African public service is unavoidable. The political environment dictates the change and the public servant of today faces a dynamic political environment in which political decisions should be executed. The conduct of the public servant is under constant scrutiny and therefore the morality of public servants should exist beyond time and should be supported by a system of values. Public servants are bound by the normative guidelines which restrain them from abusing the set rules and regulations. The contemporary South African public service is manned by officials who represent the whole spectrum of communities in South Africa - not only are they from different backgrounds, but the values of communities differ, reflecting on the morality within the public service. There should ideally be one system of values and norms for public servants, but the dilemma is that there are so many different communities. The question thus remains what or which values should be the guidelines for the public servant of today?
\end{abstract}

\section{Inleiding}

Die Suid-Afrikaanse staatsdiens het die afgelope paar jaar ongekende verandering ondergaan: daar is wegbeweeg van 'n staatsdiens waar die personeelkorps uitsluitlik bestaan het uit blanke amptenare na 'n meer verteenwoordigende staatsdiens. Die staatsdiens funksioneer binne 'n bepaalde politieke gemeenskap en hierdie politieke gemeenskap openbaar 'n eiesoortige ingesteldheid. Lede van die gemeenskap, dit wil sê die burgers van die land, is nie net bewus van eie gewaarwordinge nie, maar vind ook aansluiting by medeburgers en word sodoende bewus van gemeenskaplike/gedeelde oortuigings, waardes en norme. 
Die waardes en norme dien as raamwerk vir en fondament waarop die openbare instellings vir die betrokke gemeenskap gebou word.

Die openbare instelling, deur sy amptenare, het ten doel om die staat en sy mense te dien en die openbare amptenaar behoort hom aan dié doelstelling te onderwerp. Die openbare amptenaar beoefen 'n beroep om die gemeenskap te dien. As gevolg van die uiteenlopende sienings van die heterogeen saamgestelde staatsdiens kan etiese en moraliteitsdilemmas ontwikkel. Hierdie dilemmas word verder gekompliseer deurdat die staatsdiens uit persone saamgestel is met sowel Christelike as nie-Christelike beskouings. Die vraagstuk rondom moraliteit in die Suid-Afrikaanse staatsdiens raak al hoe meer noodsaaklik aangesien die openbare amptenaar in die belang van die breë gemeenskap behoort op te tree.

Die doel van hierdie artikel is om ' $\mathrm{n}$ indeling van bepaalde komponente en kenmerke van die onderskeie fasette van etiek en moraliteit te maak soos wat dit inslag behoort te vind in die Suid-Afrikaanse staatsdiens. Dit is dus 'n poging om 'n breë uitleg van die terrein te gee, asook die noodsaaklikheid daarvan in 'n gemeenskap. Daar word spesifiek gelet op die belangrikheid van administratiewe etiek wat die grondslag lê vir die indeling van moraliteit in bepaalde tipes en vlakke.

\section{Begripsverklarings}

Ten einde duidelikheid te verkry oor die begrippe wat in die teks verbandhoudend is, is dit van belang om dit te verklaar.

\subsection{Etos en etiek}

Etos verwys na 'n normatiewe stelsel bestaande uit spesifieke voorgeskrewe reëls. Hierdie riglyne is riglyne en voorskrifte vir aanvaarbare optrede wat aan openbare amptenare verskaf word, sodat die ideale wat kenmerkend van 'n bepaalde gemeenskap is, deur die besluite en optrede van openbare bestuurders verwesenlik kan word (Andrews, 1982:211).

Volgens Davitt (1970:238) verwys etiek na die idealistiese dimensie in die normatiewe stelsel (etos). Etiek beklemtoon die kwaliteit van lewe en daar word daarop gewys dat etiek sowel 'n filosofiese as professionele konnotasie kan hê. Voomoemde kom daarop neer dat die openbare amptenaar etiese optrede interpreteer as die korrekte morele optrede - 'n interpretasie wat in wese beteken dat die voorgeskrewe reels vir morele optrede nagekom moet word (Denhart, 1988:31).

Etiek kan beskou word as die rigsnoere wat die gedrag en optrede van openbare amptenare in die staatsdiens rig en waarna in die algemeen as morele wette verwys word. Vir die Christen beteken etiek die riglyne soos vervat in die 
Bybelse beginsels en die tien gebooie wat die wel en wee van die Christen reguleer.

\subsection{Moraliteit}

Moraliteit word vereenselwig met openbare optrede wat geskied ooreenkomstig die aanvaarde rigsnoere wat in 'n bepaalde samelewing geld. In die SuidAfrikaanse reg word drie betekenisse aan die begrip moraliteit gekoppel en word verwys na:

- godsdienstige oortuigings,

- die uitnemendheid van 'n mens se karakter en sy gedrag wat daaruit voortspruit; en

- die spesifieke sedes, waaroor die lede van die gemeenskap dieselfde mening huldig (Andrews, 1989:213).

Moraliteit is dus die absolute standaarde wat oor die grense van tyd heen bestaan. Uit bogenoemde kan afgelei word dat moraliteit verwys na reëls en standaarde wat blywend sowel as oorheersend in 'n samelewing is. Met voorgaande in gedagte beskryf Golembiewski (1965:61) moraliteit as: “... absolute standards which exist beyond time".

\subsection{Norme}

Volgens Fox en Meyer (1995:86) is norme die gedragsverwagtinge, wat gehandhaaf word deur 'n groep of individue van 'n gemeenskap asook 'n bepaalde standaard van gedrag wat verwag word. Norme kan dus beskou word as die riglyne vir aanvaarbare en wenslike gedrag wat deel uitmaak van die leefwyse van 'n bepaalde groep en word dikwels bloot as 'n gewoonte aangeneem. Norme is verder spesifieke reells wat ontwerp is ten einde sodanige optrede moontlik te maak. Openbare amptenare kan norme soos geregtigheid, gelykheid en vryheid met vrug in hul daaglikse take aanwend.

\subsection{Waardes}

Ten laaste is dit van belang om die begrip waardes toe te lig. Volgens Andrews (1989:212) berus waardes op bepaalde norme wat rasionele sosiale optrede verseker en wat met verloop van tyd kan verander. Dit moet verder onthou word dat waardes abstrak van aard is en bepaalde voorskrifte verskaf oor dit wat vir 'n bepaalde gemeenskap reg en goed is. 


\section{Etiek as onderafdeling van die filosofie}

As vertrekpunt, en met die begripsomskrywing van wat etiek behels in gedagte, is dit van belang om aan te toon dat etiek 'n onderafdeling van die filosofie is (Cambridge Dictionary of Philosophy, 1996:244 - kyk Audi, 1996). Die ander onderafdelings is die metafisika, wat die teorie van realiteit is, asook die epistemologie, wat die leer van kennis is. Die mens handel (bewustelik, toerekenbaar - hy kies) in die konkrete situasie en etiek het dus betrekking op filosofiese probleme wat ontstaan wanneer mense met mekaar in interaksie is (Welman, 1975:xv).

Dit is van belang om aan te toon dat etiek in twee onderafdelings ingedeel kan word, te wete die deontologie, wat die teorie van verpligting omvat en die aksiologie wat die teorie van waarde omvat. Voorgaande vorm die kern van etiek; waar deontologie betrekking het op die soeke na antwoorde oor watter handelinge reg is en dit dan te skei van handelinge wat verkeerd is, het aksiologie betrekking op probleme wat te doen het met goed en sleg. Dit handel dus oor waardes wat vir die mens of sosiale groep waardevol is. 'n Studie van waardes het ten doel om dit wat goed is van dit wat sleg is te onderskei (Cambridge Dictionary of Philosophy, 1996:245-246).

$\mathrm{Na}$ deontologie en aksiologie word ook verwys as meta-etiek, waar gepoog word om die betekenis van sleutelterme wat in etiese stellings voorkom te omskryf en te verklaar. Daar word ook soms daarna verwys as normatiewe etiek, waar bepaalde norme en standaarde gestel word ten opsigte van watter optredes goed of sleg is (Welman, 1975:xvi).

\section{Die noodsaaklikheid van etiek in 'n gemeenskap}

Morele norme is standaarde waarvolgens bepaalde gedragspatrone en besluite geklassifiseer en beoordeel word. Menslike gedrag, sowel in individuele as gemeenskaplike terme, word deur wette en regulasies beheer. Wette en regulasies verseker egter nie noodwendig stabiliteit en orde nie. Stabiliteit en orde word hoofsaaklik gewaarborg deur 'n mate van konsensus wat bestaan op grond van morele norme en waardes. Hierdie konsensus is die resultaat van jare van menslike interaksie, kommunikasie met verwysing na morele innovasie en worsteling met die sentrale morele aspekte van die menslike lewe. Dit word vergestalt in die nie-formele ooreenkomste waarbinne die samelewing funksioneer. Morele konsensus, as grondslag vir 'n stabiele gemeenskap, is nie altyd moontlik nie, selfs nie eens in 'n homogene samelewing nie (Cameron \& Stone, 1995:75-76). Met die verloop van die geskiedenis van die mensdom het bepaalde sentrale norme en waardes waarby mense belang het, gevestig. Volgens Gildenhuys (1991:10) is hierdie sentrale morele norme eerlikheid, regverdigheid, redelikheid, menslikheid, vryheid, betaamlikheid, integriteit en orde. Voorgaande 
bring mee dat daar staatgemaak moet word op ander mense om die sentrale morele waardes te eerbiedig. Daar moet dus 'n verbintenis tot sosiaal morele norme en waardes bestaan en dit vorm die grondslag waarsonder 'n samelewing nie suksesvol kan funksioneer nie.

\subsection{Die noodsaaklikheid van administratiewe etiek in die uitvoering van 'n openbare taak}

Ten einde die noodsaaklikheid van etiese riglyne in die uitvoering van 'n openbare taak te begryp is dit van belang om daarop te wys dat dit uit die geskiedenis van die mensdom blyk dat die administrasie van staatsaktiwiteite sedert die begin van die mensdom bestaan. Die mens het, met die oog op voortbestaan, handelinge verrig, instellings gevestig en regeerders daargestel ten einde die "beste" heil vir hul toekoms uit te werk. Die regeerders, of die stelsel nou outokraties, demokraties, aristokraties, oligargies of totalitaristies van aard is, het die verantwoordelikheid om die primêre staatsfunksies ten uitvoer te bring. Vir hierdie doel word openbare amptenare aangestel om wette te maak ten einde vrede en orde te handhaaf, fondse te in en die fondse sodanig aan te wend dat die wette ten uitvoer gebring word (Botes et al., 1992:1)

Aangesien daar met openbare fondse gewerk word, is dit van belang dat bepaalde riglyne daargestel word, soos byvoorbeeld wetgewing, regulasies en kodes waarvolgens die openbare amptenaar die fondse moet aanwend. Riglyne is van belang om menslike handelinge en gedrag te orden. Hierdie riglyne verskaf aan die openbare amptenaar 'n maatstaf vir korrekte optrede te midde van 'n onvolmaakte samelewing. Dit is van belang om te meld dat in die publieke administrasie, die terrein waarop die studie van Publieke Administrasie as vakwetenskap toespits, die etiese handelinge verder strek as slegs die verhouding tussen mense. Die instelling (staat) kom ook as vennoot ter sprake. In hierdie verband stel Botha (1993:172) dit duidelik dat die staat geensins daargestel word as eiemagtige, selfstandige en outonome mag naas en teenoor God of die mens nie - inteendeel, die staat is juis aangewys op en afhanklik van die versorging en bewaring deur die mens.

Openbare amptenare se aksies behoort dus gerig te wees op die bevordering van die algemene welsyn en die uitbouing van die openbare belang. Caiden soos aangehaal in Cameron en Stone (1995:76) toon ook aan dat etiek, soos wat dit behoort te manifesteer in die openbare sektor, alreeds deur Cicero in sy werke $D e$ Officiis voorgestel is deurdat Cicero soos volg daarna verwys het:

Those who mean to take charge of the affairs of government should not fail to remember two of Plato's rules: first to keep the good of the people clearly in view that, regardless of their own interests, they will make their every action conform to that; second, to care for the welfare of the whole body politics and not in serving the interests of some one party to betray the rest. For the 
Toepassing van moraltelt in dle Suid-Afrlkaanse stadsdlens

administration of the government, like the office of a trustee, must be conducted for the benefit of those entrusted to one's care, not of those to whom it is entrusted.

Bogenoemde is in beginsel korrek, maar dit is nodig om te meld dat dit waarin die openbare amptenaar glo, hetsy vanuit die Christendom, Islam, ensovoorts, gebaseer is op sy evaluering van wat as reg beskou word en vanuit die raamwerk van sy geloofsoortuiginge en dat hy dit dan dienooreenkomstig interpreteer. Dit skep uit die aard van die saak 'n gekompliseerde aangeleentheid aangesien die etiese beginsels, norme en waardes wat op grond van geloofsoortuiginge verantwoordbaar is oor wat "goed" of "sleg" of wat "reg" en "verkeerd" is, nie vir almal eenders is nie en dus nie vir almal bindend is nie. Verder kan dit soms ook gebeur dat die openbare amptenaar meer begaan is oor die primêre ek (homself), dat hy homself in ag neem en doelwitte alleen in die lig van homself formuleer met ander woorde die primêre objek waarop gefokus word, is die self. Met voorgaande in gedagte en waar die Suid-Afrikaanse staatsdiens heterogeen saamgestel is, is dit van belang om die tipes en vlakke van moraliteit taksonomies aan te toon ten einde ' $n$ begrip van moraliteit in die staatsdiens te kan vorm.

\section{Taksonomiese indeling van moraliteit wat in die staatsdiens van toepassing gemaak kan word}

Moraliteit in die staatsdiens is gemik op optredes in die nakoming van bepaalde waardes wat ondersteun word deur aanvaarde norme, ooreenkomstig 'n bepaalde voorgeskrewe etiese kode en met inagneming van persoonlike sedes. Dit is dan ook so dat dit geen maklike taak vir openbare amptenare is om besluite te neem wat te alle tye as moreel geregverdig aanvaar word nie. Openbare amptenare word gewoonlik van spesifieke reels, te wete wette, regulasies en prosedurehandleidings voorsien waarvolgens hulle besluite kan neem, maar min of geen aanbevelings word gemaak oor die waardes wat in die proses eerbiedig moet word nie. Indien daar geen voorskrifte bestaan nie, kan dit gebeur dat die openbare amptenaar dit kan beskou as ' $n$ implisiete boodskap dat alle besluite wat toegepas word, aanvaarbaar is - met dien verstande dat die korrekte metode, dit wil sê die metode soos vervat in wette en regulasies, asook in prosedurehandleidings, toegepas word en sodoende geregverdig is (Denhart, 1988:125). Die nodige leiding behoort dus deur middel van ' $n$ kode daargestel te word en indien daar geen leiding verskaf word nie, is openbare amptenare daarop aangewese om op hulle persoonlike sedes te vertrou of om op die beskikbare instrumentele rasionaliteit staat te maak. Dit behoort egter beklemtoon te word dat dit geen waarborg is dat die besluite wat hulle neem, in openbare belang is of aan die vereistes van sosiale moraliteit voldoen nie.

Ten einde rigting te kan gee aan die tipes van moraliteit wat op openbare amptenare van toepassing kan wees, word bepaalde artikels soos vervat in die 
Gedragskode vir lede van die Staatsdiens, Kennisgewing 5947 van 1997 as besprekingspunt voorgehou.

\subsection{Basiese eerlikheid en konformiteit aan die reg}

Die openbare amptenaar is in die uitvoering van die opgelegde taak nie verhewe bo die landswette nie, maar is net soos die gewone landsburger onderworpe aan die landswette. Die openbare amptenaar kan slegs dit doen wat deur middel van wetgewing opgedra word. Artikel M4.1.1 van Kennisgewing 5947, 1997, oor die gedragskode vir staatsamptenare bepaal immers dat die openbare amptenaar die Grondwet eerbiedig en aanvaar as rigsnoer in die uitvoering van sy dagtaak.

Daar rus ' $n$ morele verpligting om met daardie wette te konformeer want die openbare amptenaar behoort immers 'n voorbeeld te stel (Willbern, 1984:103). 'n Geordende samelewing kan nie bestaan indien die burgers van die land slegs die wette volg wat hulle wil nie. Dit is egter van belang dat die wetgewing redelik en billik moet wees (Boling \& Dempsey, 1980:11) anders kan dit aanleiding gee tot burgerlike ongehoorsaamheid. Daar word dus staatgemaak op die sosiale verbintenisse en verpligtinge van ander individue (medelandsburgers) en dit word verwag dat ander behoort te konformeer met betrekking tot die instandhouding van daardie bepaalde norme van optrede

Voorgaande is egter nie so eenvoudig nie aangesien die mens, en in dié geval ook die openbare amptenaar, in 'n gebroke wêreld funksioneer. Daar is leuenaars, diewe en diegene wat die wet verbreek deur onaanvaarbare optrede na te volg wat tot hul eie voordeel strek. In die geval van die openbare amptenaar word bepaalde mag en gesag deur middel van wetgewing toegeken. Dit kan dus die gevaar meebring dat daar meer geleenthede is vir die oortreding van die morele kode. Mag en toegang tot openbare goedere soos openbare fondse en veral roerende eiendom bring meer versoekings; die lewering van dienste aan die publiek mag lei tot beroepsontrouheid deur beloftes te maak wat nie kan realiseer nie, of die openbare amptenaar kan "traag" wees in die uitvoering van 'n diens.

Ten einde die geleenthede vir die oortreding van die morele kode te verminder, is dit van belang dat minder magte in die staatsbestuur gesetel behoort te wees. Alhoewel die privaatsektor ook nie totaal verhewe is bo misbruik nie, kan dit tog 'n mate van verskansing teen die misbruik van openbare eiendom bied (byvoorbeeld die manipulering en ongewenste metodes om staatskontrakte deur middel van tenders te bekom) en behoort dit tot minder korrupsie te lei. Verder is die uitbreiding en die versterking van die regstelsel ' $n$ vername bydrae aangesien die openbare amptenaar onder dieselfde regstelsel geoordeel word as die gewone landsburger. Die rol van die openbare media om die misbruik van toegekende magte aan die kaak te stel behoort nie gedemp te word nie. Dit is wel so dat die 
owerheid te enige tyd kan besluit om deur middel van wetgewing die media se rol as rapporteerder aan bande te lê.

Ten laaste 'n opmerking oor eerlikheid - 'n grys area - soos wat dit van toepassing behoort te wees, vanaf die kant van die openbare amptenaar. Soos aangetoon deur Gildenhuys (1991:10) en gestel deur Cicero (aangehaal in Caiden, 1982:7) is een van die sentrale norme eerlikheid. Dit beteken dat die openbare amptenaar nie leuens behoort te vertel in die uitvoering van werk nie aangesien dit die vertrouensposisie tussen die openbare amptenaar en die gemeenskap kan skaad (Hart, 1984:118).

Daar is egter wel uitsonderings op die morele reel, te wete waar 'n amptenaar byvoorbeeld in die openbare instelling se Afdeling: Finansies werksaam is en belas is met die taak om tenders te kry. Dit gebeur soms dat 'n potensiële tenderaar die amptenaar nader of probeer omkoop deur sake-etes of ander gunste, ten einde vas te stel wat die bedrag is wat die openbare instelling begroot het vir die projek. Ten einde alle tenderaars 'n gelyke geleentheid te bied is dié inligting uiteraard vertroulik. Die openbare amptenaar is dan genoodsaak om in die geval vaag te wees en nie die waarheid oor die tenderbedrag oor te dra nie. 'n Verdere voorbeeld is waar die polisie informante soms betaal om kriminele aan die kaak te stel. In hierdie geval word die openbare belang dus beskerm al word die grense van die morele kode om eerlik te wees, oortree. Dit is nodig om daarop te wys dat hierdie voorbeelde uiters moeilike etiese areas verteenwoordig omdat die doel die middele regverdig en dus die bestaansrede van die morele regverdiging verskaf.

\subsection{Botsende belange}

'n Verdere gebied van potensiële etiese konflik is die terrein van botsende belange (Denhardt, 1991:119). Konflikterende of botsende belange dui op die onversoenbaarheid tussen private belange van openbare amptenare en hulle amptelike pligte (Fox \& Meyer, 1995:25). Die algemene aanname is dat dit die morele plig van die openbare amptenaar is om die "openbare belang" na te streef, dit wil sê om na die behoeftes en algemene welsyn van die samelewing om te sien. Dit beteken in die suiwerste vorm dat die persoonlike belange van die openbare amptenaar en die persoonlike belange van daardie gedeelte van die gemeenskap waarvan hy/sy lid is, ondergeskik behoort te wees aan die belange van die breë samelewing (kyk par. $4.1 \&$ Hart, 1984:117).

Alvorens die onderskeie artikels van die Gedragskode vir lede van die Staatsdiens op begenoemde aspek toegepas kan word, is dit van belang om die volgende onderskeid te tref:

- konflikterende belange in private aangeleenhede, en

- konflikterende belange in openbare aangeleenthede. 
Konflikterende belange in private aangeleenthede dui op die nastreef van selfbelang deur elke deelnemer en die effektiefste wyse om die algemene belang te verseker (Willbem, 1984:104). Konflikterende belange in openbare aangeleenthede deur private ekonomiese entiteite in oorleg met die owerheid is een van die groot oorsake van morele dilemmas in die openbare sektor. Die hedendaagse owerheid het 'n geweldige impak op ekonomiese aktiwiteite deur middel van belastings en begrotings. Dit is egter die nastreef van sekere beleidsprioniteite en die ekonomiese impak daarvan op die gemeenskap wat problematies blyk te wees. Die rede hiervoor is dat dit wat vir die een deel van die gemeenskap tot voordeel strek, op sy beurt vir 'n ander deel van die gemeenskap tot nadeel is. 'n Ekonomiese balans is dus van absolute belang vir die doeltreffende nastreef van beleidsprionteite.

Artikel M4.4.1 van Kennisgewing 5947 van 1997 wys daarop dat die openbare amptenaar eerlik in die hantering van openbare fondse behoort te wees en dat staatseiendom ekonomies benut behoort te word - en dan slegs vir amptelike doeleindes. Artikel M4.5.3 bepaal dat die openbare amptenaar nie sy amptelike posisie mag gebruik ten einde finansiële of ander voordele vir homself, sy familie of enige ander persoon of organisasie na te jaag of te verkry nie. Genoemde artikels is egter nie duidelik en spesifiek genoeg nie en laat ruimte vir misbruik en oortreding. Die verduistering van openbare fondse en wanaanwending kan voorkom wanneer die oortreders (openbare amptenare) hul persoonlike belange bo dié van die breë samelewing nastreef en waar die amptelike wette, regulasies en morele kode oortree word. Persoonlike belange kan bevorder word wanneer die amptenaar byvoorbeeld 'n amptelike besoek gebruik as 'n semi-vakansie of om vriende of familie te besoek of as hy die amptelike voertuig gebruik om inkopies te doen.

Ten einde die misbruik van openbare fondse in die uitvoering van amptelike aangeleenthede sover moontlik aan bande te lê is dit van belang dat diegene wat verantwoordelik is vir die administrasie en bestuur van die openbare instelling die toepaslike kodes deur interne kontrolemaatreëls aanvul. Hierdie inteme kontrolemaatreëls se doel behoort nie te wees om amptenare uit te vang nie maar eerder om hul gedrag te reel en reguleer. Daar moet egter gewaak word teen begrippe soos "dit is in die belang van die gemeenskap", "regverdig", "noodsaaklik", "voordelig", "prakties" of "genoegsaam" (of die teenoorgestelde woorde) in die interne kontrolemaatreëls, aangesien dit 'n waardeoordeel bevat wat moontlike wanaanwending van openbare fondse kan regverdig.

Artikel M4.2.7 van reeds genoemde Kennisgewing bepaal onder meer dat geen openbare amptenaar van sy posisie in die Staatsdiens gebruik mag maak om die belange van enige politieke party of belangegroep te bevorder of benadeel nie. Met voorgaande in gedagte is dit ook so dat sommige openbare amptenare, voor die aanvaarding van die openbare amp, in mindere of meerdere mate betrokke was by die een of ander groep(e), hetsy godsdienstig, polities of in professionele hoedanigheid. Dit is dus moontlik om te aanvaar dat die belange van daardie groep(e) 
mag ooreenstem met die belange van die breë samelewing, maar dit is ook so dat daar ander groepe is wie se belange met daardie groep en dus in wese met die openbare amptenaar se standpunt mag verskil. Dit kan ook gebeur dat die invloed deur die politieke party sodanig mag wees dat 'n spesifieke persoon of belangegroep begunstig kan word, of dat die openbare amptenaar die wetgewing gebruik om sekere dele van die gemeenskap te bevoordeel.

Voorgaande is tipiese voorbeelde van konflik van belange en is dus kompleks van aard. Dit is so dat dit nie altyd maklik is om presies te bepaal of die besluit wat die openbare amptenaar neem, eties is al dan nie. Daarom behoort openbare amptenare hul eie persoonlike etiese standaarde te ontwikkel. Hulle is immers daarvan bewus dat die vertroue van sommige belangegroepe of al die lede van die publiek op die spel is, aangesien hulle gesamentlik of afsonderlik deur sodanige besluite geraak kan word en gevolglik daarvoor aanspreeklik is. Dit is tog nodig om daarop te wys dat die openbare amptenaar soms aan homself oorgelaat word om bepaalde besluite te neem oor wat reg is, omdat dit as algemeen aanvaar word dat almal bewus is van wat 'n morele oordeel is (Andrews, 1989:216). Dit behoort egter onderskryf te word dat vele versoekings op die pad van die openbare amptenaar kom vanweë sy gesagsposisie of verbintenis tot 'n bepaalde politieke party of belangegroep.

Ten einde die probleem te ondervang, is die wyse waarop die openbare amptenaar die probleem hanteer, van belang. Indien dit mikro-eties (Plant \& Gortner, 1980:4) nagevolg word, beteken dit dat die openbare amptenaar homself as die doelwit beskou om sodoende sy mag en status uit te bou. Dit is dus van belang dat die openbare amptenaar 'n makro-etiese benadering behoort te volg wat beteken dat die individule aspirasies, begeertes en gevoelens ondergeskik gestel word aan die belange van die gemeenskap.

Konflikterende belange gaan volgens Wronsley (1989:16) veel verder omdat 'n konflik ontstaan as gevolg van die uitvoering van politieke en wetlike opdragte. Dit kan derhalwe daarop neerkom dat 'n openbare amptenaar 'n opdrag moet uitvoer wat teenstrydig is met sy persoonlike oortuigings, standpunte en geloofsoortuigings. Verder is daar die persoonlike konflikterende belange wat impliseer dat 'n openbare amptenaar 'n opdrag moet uitvoer wat die betrokke openbare amptenaar of enige ander persoon na aan die amptenaar tot nadeel sal strek. Dan is daar die konflik tussen die gewete en selfbehoud wat ontstaan wanneer 'n openbare amptenaar deur sy onmiddellike hoof verplig word om oneties op te tree. Die openbare amptenaar word dus voor 'n keuse gestel, deur 'n direkte of indirekte handeling, om 'n onetiese handeling te verrig of om die handeling nie te verrig nie

\subsection{Diensoriëntasie en proseduriële geregtigheid}

Met betrekking tot diensoriëntasie en prosedurièle geregtigheid bepaal Artikel M4.4 van Kennisgewing 5947 van 1997 onder meer dat 'n openbare amptenaar verbind 


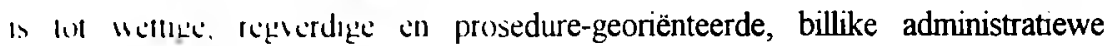

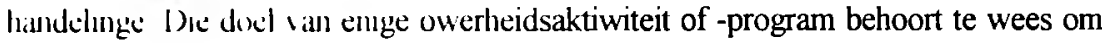
'n diens tc lewer aan sy kliënte, te wete die publiek. Selfs wanneer daar 'n mate van beheer of gesag utgeoefen word, word steeds 'n diens gelewer (Gildenhuys, 1991:22). Die gevaar bestaan egter dat die uitvoerende gesag van die amptenare dienslewerings kan oorskadu. Dit is hier waar 'n terrein betree word waar private moraliteit intree, wat minder sigbaar en waameembaar is en waar die probleme van meer buitengewone aard is.

Die houding en gesindhede van amptenare neig dikwels om aanleiding te gee tot 'n morele kwessie. Die toekenning van gesag kan dikwels lei tot die ontstaan van arrogansie en onbetrokkenheid vanaf die kant van die openbare amptenaar - 'n gesindheid wat die bereıdwilligheid om die publiek te dien kan vervang. Die belange van die openbare amptenaar word sodoende vooropgestel ten koste van die belange van die publiek. Vertragings en geheimhouding kan dus algemeen aanvaarde praktyk word (Willbern, 1984:105).

In die lewering van 'n diens aan die gemeenskap word van die openbare amptenaar verwag om te alle tye vriendelikheid en hulpvaardigheid aan die dag te lê. Dit is egter hier waar die morele gevaar skuil; die openbare amptenaar kan deur middel van 'n verskeidenheid vorme van regulerende dokumentasie gedwing word om vriendelikheid en hulpvaardigheid aan die dag te lê, dit in die uitvoering van die taak oënskynlik doelgerig uitvoer, maar tog 'n soort van vertraging bewerkstellig. Aangesien die lede van die publiek nie altyd kennis het van die werksaamhede nie, sal dit uiteraard moeilik wees om te bepaal of die openbare amptenaar nougeset optree al dan nie.

\subsection{Die etiek van demokratiese verantwoordelikheid}

Die grondslag vir die bestaan van etiese en demokratiese verantwoordelikheid berus op Artikels M4.1.1 en M4.1.3 van Kennisgewing 5947 van 1997, waar eersgenoemde bepaal dat die openbare amptenaar die Grondwet moet eerbiedig en dit moet aanvaar as rigsnoer in die uitvoering van sy dagtaak. Laasgenoemde artikel bepaal dat die openbare amptenaar daartoe verbind is om in die uitvoering van sy administratiewe funksies die beleid van die regerende party getrou en lojaal uit te voer.

In die eenvoudigste veralgemening van openbare mening kan geargumenteer word dat 'n demokratiese stelsel "goed" is en 'n ondemokratiese stelsel "sleg" is. Die doel van 'n demokrasiestelsel is om toestande te skep waarin die lede van die gemeenskap die grootste mate van voorspoed sal ervaar (Bayat \& Meyer, 1994:36). In die eenvoudigste vorm kan die werking van die demokrasie soos volg toegelig word. Die legitimiteit van openbare beheer word oorgedra na die openbare amptenare deur middel van delegering. Die Wetgewende Gesag is veronderstel om te doen wat die 
meerderheid van die gemeenskap wil hê, terwyl die Uitvoerende Gesag weer by die Wetgewende Gesag moet aanpas in die uitvoering van die wil en wense van die meerderheid van die gemeenskap. Die openbare amptenare is dus eties verbind tot die uitvoering van die instruksies van die politici, wat weer op hulle beurt legitimiteit vir hul besluite van die meerderheid van die gemeenskap verkry (Willbem, 1984:106).

Daar moet egter ook gereelde konsultasie plaasvind tussen die regering en die gemeenskap - 'n werkwyse wat sal lei tot harmonie in die samelewing (Bayat \& Meyer, 1994:36). Ten spyte van die stelling dat demokrasie omskryf kan word as "regering van die volk, vir die volk, deur die volk" sal daar in 'n demokratiese staat steeds 'n klein aantal persone wees wat beklee is met die wetlike gesag om besluite te neem wat op die gemeenskap afgedwing sal kan word. Vir die behoud van die grondslae van die demokrasie moet die regeerders egter so georganiseer word dat hulle die gesag waarmee hulle beklee is, nie vir hul eie belang of die belang van slegs bepaalde bevolkingsgroepe sal misbruik nie (Cloete, 1993:760).

Ten einde die moontlike misbruik van gesag te voorkom is dit van belang dat die lede van die gemeenskap oor spesifieke regte en voorregte beskik. Die aktiwiteite van openbare instellings moet waargeneem, ondersoek en gemonitor word (Bayat \& Meyer, 1994:37). Owerheidshandelinge moet waar moontlik in die openbaar geskied en nie agter ' $n$ gordyn van geheimhouding nie. Daarom word daar in die demokratiese staat na openbare of publieke administrasie verwys (Cloete, 1993:77). Dit moet in gedagte gehou word dat geheimhouding soms tot 'n geleentheid vir onetiese optrede mag lei. Alhoewel geheimhouding ten opsigte van aspekte soos nasionale veiligheid 'n sekere mate van regverdiging het, moet gewaak word teen die oorbeklemtoning daarvan (Bayat \& Meyer, 1994:37)

Verder is dit noodsaaklik dat die individuele lid van die gemeenskap of groep(e) wat die handeling waargeneem of ondersoek het, oor die nodig bevoegdheid en vryheid van optrede beskik om 'n mening oor die owerheidshandeling uit te spreek. Vryheid van spraak moet dus toegelaat word. Dit is verder noodsaaklik dat individuele lede van die gemeenskap ook oor die nodige vryheid van beweging beskik. Deur hulle vryheid van spraak en beweging gesamentlik toe te pas, verkry die individuele lede van die gemeenskap dus ook vryheid van vergadering en vereniging (Cloete, 1993:77).

Die etiek van demokratiese verantwoordelikheid skep egter vele probleme vir die openbare amptenaar. Algemene probleme in hierdie opsig sluit die volgende in:

- Openbare amptenare (as individue) beskik gewoonlik oor hulle eie waardes, norme en doelwitte, wat mag verskil van die waardes van die regerende party. 
- Die vraag ontstaan of die openbare amptenaar moet doen wat die breë gemeenskap wil hê hy/sy moet doen en of moet hy/sy doen wat hy/sy dink hulle wil hê.

- Die kennis van die breë gemeenskap ten opsigte van sekere beleidsaspekte is dikwels onvolledig. Die openbare mening word dikwels gevorm op grond van foutiewe en onvolledige inligting (Willbern, 1984:106)

Uit die voorafgaande kan die afleiding gemaak word dat owerheidshandelinge aan bepaalde etiese norme moet voldoen. Ook kan gesê word dat diegene wat met die nodige gesag beklee is, sodanige gesag in wese in trust vir die gemeenskap hou.

\subsection{Die etiek van openbare beleidbepaling}

Aangesien die meeste openbare aktiwiteite met beleidsformulering en -uitvoering in verband staan, is dit van belang dat twee aspekte ontleed word. Die etiese bepaling van beleid en die formulering van beleid moet aan twee vereistes voldoen, te wete intellektuele en normatiewe vereistes.

\section{- Intellektuele vereistes}

Wat intellektuele vereistes betref, is dit noodsaaklik dat die formulering aan bepaalde vereistes moet voldoen - soos onder meer taalkundige korrektheid en logiese denke. Benewens hierdie vereiste is daar ook bykomende vereistes waaraan voldoen moet word tydens die opstel en bepaling van beleid. Hierdie vereistes is volgens Meehan (1987:7-9) die volgende:

- Die kapasiteit van die persoon belas met die formulering van beleid word as eerste vereiste gestel. Die substansie van 'n keuse word bepaal deur die kapasiteit van die beleidmaker. Ook berus die regverdiging van 'n keuse vir 'n spesifieke aksie op ' $n$ vergelyking tussen die resultate en die keuses wat beskikbaar is.

- Regverdiging van aksies moet plaasvind voordat aksies uitgevoer word. Dit kan gedoen word deur gebruik te maak van teorieë. Teorieë word gebruik om 'n vergelyking te tref tussen voorgestelde aksies en dan die mees toepaslike aksie te kies

- Alle aksies wat geneem word, moet gegrond wees op regverdige behandeling Die regverdiging van een voorkeur bo ' $\mathrm{n}$ ander moet dus verwys na die kondisie van die lewenstandaard van 'n geselekteerde groep. Die keuse wat gemaak word, moet vir die grootste deel van die bevolking tot voordeel strek.

- Indien twee of meer resultate vir die beleidmaker beskikbaar is, moet een resultaat bo die ander verkies en geregverdig word. Dit impliseer dat daar sekere prioriteite 
moet wees. Prioriteite word geregverdig wanneer gedemonstreer word dat dit die gewensde resultate sal lewer wanneer dit in die werklike situasie gebruik word

- Wanneer die gewensde resultaat bepaal is, moet dit omskep word in 'n beleid waarvolgens aksie-georiënteerde programme uitgewerk moet word. Beleid is dus die instrument wat gebruik word om prioriteite te omskep in aksies.

- Verder is dit van belang dat 'n doeltreffende moniteringstelsel behoort te bestaan. Tenugvoering van aksies is nodig om te bepaal of die beleid in sy doel geslaag het al dan nie. Die monitering van beleid is nodig omrede daar altyd 'n mate van onsekerheid sal bestaan wanneer met menslike vermoëns gewerk word.

\section{- Normatiewe vereistes}

Met die intellektuele vereistes in gedagte is dit belangrik dat die beleidmaker moet besef dat daar nie slegs op intellektuele en akademiese kennis staatgemaak kan word nie. Die gebruik van normatiewe vereistes is 'n verdere noodsaaklike komponent (Meehan, 1987:11). Normatiewe kennis identifiseer menslike situasies wat volgens normatiewe vereistes onaanvaarbaar is. Verder word menslike aksies geïdentifiseer wat die potensiaal besit om normatief-aanvaarbare situasies te skep en ten laaste word die gewensde resultaat vanuit die beskikbare alternatiewe geselekteer.

Tydens die beoordeling van die regverdiging van 'n bepaalde beleid is dit van belang dat die volgende oorwegings in ag geneem word:

- Die kostevoordeel-analise wat impliseer dat elke aksie of beleid se voordele opgeweeg en vergelyk moet word met die nadele of kostes. Die voordele moet gemaksimaliseer en die kostes sover as moontlik geminimaliseer word.

- Die problematiek van verspreiding, wat impliseer wie wat kry en wie dus meer ontvang. Die verspreiding van voordele vir een groep ten koste van 'n ander groep sal dus duidelik gemotiveer en omskryf moet word (Meehan, 1987:10).

Kostevoordeel-analise is egter nie so eenvoudig soos wat dit voorkom nie. As gevolg van besnoeiings op begrotings en prysstyging is openbare amptenare wat met begrotings werk, geneig om meer te begroot as wat werklik nodig is. Verder, wanneer die begrotingsjaar eindig en die oorblywende fondse in die staatskatkis teruggestort moet word, gebeur dit dat die gelde onoordeelkundig bestee word op lae prioriteite eerder as om die fondse terug te stort. Goed gemotiveerde motiverings word dan gegee om die gelde sodanig te bestee. Die implikasie hiervan is tweeledig van aard: ten eerste kan dit gebeur dat toekomstige begrotings kunsmatig vermeerder word, en ten tweede kan die kunsmatige invloed op die bestedingspatroon in die algemene ekonomie die pryse van goedere en dienste verloog in Verdere grys area wat die minimalisering van kostes betref, is waar openbire amptenate goed gemotiveerde voorstelle voorlê om bepaalde projekte geloods te hru l)iar kan 
byvoorbeeld 'n projek wees vir die bou van 'n pad reg deur die middel van 'n ekologies-sensitiewe gebied aangesien dit die goedkoopste metode is en dus ook vir die padgebruiker koste bespaar. Die openbare amptenaar word dus in 'n dilemma geplaas omdat 'n keuse gemaak moet word tussen die private belange van 'n bepaalde groep in terme van koste en die belange van die breë gemeenskap.

Met betrekking tot die etiek in openbare beleidbepaling is dit van belang om daarop te wys dat die openbare amptenaar tydens beleidsformulering nie slegs op akademici moet staatmaak vir die formulering van 'n etiese raamwerk nie. Sekere aangeleenthede kan nie vanuit geskrifte geleer word nie, aangesien dit in die openbaar getoets moet word aan die hand van die beskikbare bronne

\subsection{Die etiek van skikking en sosiale integrasie}

In 'n snel veranderende land soos Suid-Afrika met sy heterogene samestellıng is die nastrewing van sosiale integrasie asook die kompensering van belange en behoeftes 'n navolgenswaardige doelwit. Willbern (1984:107) toon aan dat mense in 'n land moet saamleef, mekaar moet verdra, moet aanpas by mekaar en bereid moet wees om sekere opofferings te maak. Die mens kan egter nie wegkom van die feit dat hy in 'n politieke omgewing leef wat hoogs veranderlik is nie. Daar moet dus gepoog word om te midde van politieke verskille 'n goue middeweg te vind. Sowel die landsburgers as die openbare amptenare moet dus die politieke aspirasies van openbare instellings en individue aanvaar en respekteer. Nasiebou vorm dan ook een van die ses grondbeginsels van die Heropbou en Ontwikkelingsprogram (HOP) en word beskou as die grondslag waarop effektiewe ontwikkeling sal kan plaasvind vir die ontwikkeling van byvoorbeeld 'n ekonomies vooruitstrewende land (The Reconstruction and Development Programme, 1994:7)

\section{Gevolgtrekking}

Die openbare amptenaar behoort iemand te wees wat sy eie belange en behoeftes ondergeskik stel aan die belange en behoeftes van die samelewing as geheel. Hierdie doelwit is egter nie so eenvoudig nie aangesien die mens in 'n gebroke wêreld funksioneer en dit kan gebeur dat die openbare amptenaar begin om sy belange bo dié van die gemeenskap te stel. So 'n ingesteldheid impliseer dat die openbare amptenaar 'n mikro-benadering volg waar die "self" die belangrikste word.

In die toepassing van openbare moraliteit is dit van belang dat kennis van die volgende gedra moet word:

- Die verbetering en uitbouing van die regstelsel waar oortredings van die morele kode so spoedig moontlik gehanteer word. 
- Openbare media se rol moet beklemtoon word en nie deur wetgewing beperk word nie. Dit is die taak van die openbare media om die belange van die samelewing op die hart te dra en oor sake wat skadelik is te berig.

- Interne kontrolemaatreëls moet uitgebou word en aanvullend wees tot die beskikbare regulasies en kodes, ten einde oortreders van die morele kode so vinnig moontlik tot openbare aanspreeklikheid te bring.

- Die publiek moet ingelig gehou word oor die aktiwiteite van openbare instellings.

- Openbare aanspreeklikheid moet versterk word deur die Wetgewende Gesag. Onafhanklike instellings soos byvoorbeeld die Ouditeur-generaal en Openbare Beskermer se magte en funksies kan dus uitgebrei word - ook ten opsigte van die ondersoek na oortredings van die morele kode.

- Gemeenskapsbetrokkenheid moet uitgebou word deur middel van openbare fonums of vergaderings waar lede wat ' $n$ bepaalde groep(e) verteenwoordig, hul saak in die openbaar kan stel.

- 'n Etiese kultuur moet gekweek word. Sodanige kultuur moet reeds op skoolvlak in werking gestel word om sodoende 'n algemene trots vir die land te bou.

Dit is egter nodig om te meld dat met die toepassing van openbare moraliteit gewaak moet word teen die oormatige instelling van regulerende maatreëls aangesien die openbare amptenaar so besig kan wees om dit te bestudeer ten einde dit nie te oortree dat dit weer aanleiding kan gee tot 'n verlaging in produktiwiteit en dienslewering Oormatige maatreëls kan ook 'n demper plaas op kreatiewe en innoverende denke wat so belangrik is in 'n land waar ingrypende politieke en ekonomiese verandering aan die orde van die dag is. Verder, alhoewel dit sekerlik nie totaal moontlik is nie, is dit tog van belang om politieke invloede sover moontlik van die operasionele administrasie te skei.

Ten laaste is dit nodig om te meld dat die kwaliteit van die openbare amptenaar 'n deurslaggewende rol kan speel. In hierdie opsig is dit dus van belang dat daar tydens aanstellings nie slegs staatgemaak moet word op die voer van onderhoude nie, aangesien persone met 'n sterk verbale oorredingsvermoë die paneel met daardie vermoëns kan beïndruk. Daar behoort verder gegaan te word deur byvoorbeeld takseersentrums en simulasies te benut om die ware gesindheid van die openbare amptenaar te bepaal. Ook kan die gebruik van 'n kontrakaanstelling oorweeg word. Sodoende word weggedoen met die situasie dat die openbare amptenaar weet dat hy in die instelling is tot en met aftrede. ' $n$ Etiese bewustheid kan moontlik verbeter word deur openbare amptenare die nodige opleiding en blootstelling in etiese optrede te verskaf en beskerming te verleen aan verklikkers (whistle-blowers). Hierdie is slegs enkele metodes wat benut kan word in die nastreef van morele bewustheid 


\section{Bibliografie}

ANDREWS, Y 1982 Die personeelfunksie. Pretoria : HAUM

ANDREWS, Y. 1989. Moraliteit en die eise wat aan Openbare Bestuurders gestel word. SuidAfrikaanse Instituut vir Publieke Administrasie, 24 (4) 213, 216.

AUDI, R ed 1996. The Cambridge Dictionary of Philosophy. Cambridge : Cambridge University Press

BAYAT, M S. \& MEYER, I.H. 1994 Public Administration: Concepts, theory and practice Pretoria : Southem Book Publishers

BOLING, T.E. \& DEMPSEY, J. 1980. Ethical dilemmas in government: design and organizational response Public Personmel Management Journal. 11, Nov.

BOTES, P.S., BRYNARD, P.A., FOURIE, D.J \& ROUX, N.L. 1992. Publieke Administrasie en Bestuur - 'n Handleiding in Sentrale, Regionale en Munisipale Administrasie en Bestuur. Pretoria : HAUM

BOTHA, E. 1993. Metateoretiese perspektiewe op die sosiale wetenskappe Potchefstroom Departement Sentrale Publikasies

CAIDEN, G E. 1982. Public Administration California : Palisades Publishers

CAMBRIDGE DICTIONARY OF PHILOSOPHY Kyk AUDI, R ed. (1996)

CAMERON, R.G. \& STONE, A B. 1995. Serving the public: A guide for practitioners and students. Pretoria : Van Schaik

CLOETE, J.J.N. 1993. Publieke Administrasie en Bestuur Kaapstad : Van Schaik.

DAVITT, T.E. 1970. The ethics in the situation. New York : Appleton-Century-Crofts.

DENHART, R.B. 1988. The ethics of Public Service: resolving moral dilemmas in public organizations New York : McGraw-Hill

FOX, W. \& MEYER, IH. 1995. Public Administration Dictionary. University of Stellenbosch : Juta.

GILDENHUYS, J S.H 1991. Ethics and the public sector Cape Town : Juta

GOLEMBIEWSKI, R T. 1965. Men, management and morality: toward a new organizational ethic New York : McGraw-Hill.

HART, D.K. 1984. The virtuos citizen, the honorable bureaucrat, and "Public" Administration Public Administration Review, 44:117, 118

MEEHAN, E.J. 1987. Ethics for policy making and Public Administration. Politela, 6(2):7-1 1

PLANT, J.F. \& GORTNER, H.F. 1980. Ethics, personnel management and civil service reform. Public Personnel Management Journat 4, Nov

SUID-AFRIKA (REPUBLIEK). Kennisgewing 5947 van 1997. Die daarstelling van 'n gedragskode vir lede van die Staatsdiens. Pretoria : Staatsdrukker.

The RDP Reconstruction and Development Programme. 1994 Cape Town : ABC Printers.

WELLMAN, C 1975 Morals \& ethics. Glenview, Illinois : Scott \& Fresman

WILLBERN, Y. 1984. Types and levels of public morality. Public Administration Review, 44(2): 103-107

WRONSLEY, R.P. 1989. Does the dictum of political supremacy cause conflict with public officials? Suid-Afrikaanse Institunt vir Publieke Administrasie, 24(4): 16 